stock and not, as previously supposed, a laccolith. He identified the components of the Carrock Fell igneous complex and inferred that they were intruded as steeply inclined sheets or elongated lenses after the main Caledonian folding and during a trough-like subsidence of the region. He also threw light on the glacial retreat phenomena of western Edenside and the Solway Basin, drainage problems of the River Eden and solifluxion phenomena. Inspired by data from Cumberland he made a statistical analysis of high-level erosion surfaces in Britain.

After two years spent mapping in the Droitwich neighbourhood he was transferred to work on the one-inch maps of the Huntingdon and Cambridge areas. In the war years he worked mainly on the structure, stratigraphy and reserves of the sedimentary iron ore field developed in the Northampton, Wellingborough and Kettering areas. As a substantial legacy to geology he contributed a demonstration, with other colleagues, that some structures revealed in the Jurassic rocks in the ironstone field were superficial Pleistocene features caused by adjustment forces producing valley bulging and valloy side cambering. In all, Hollingworth was part author of twelve of the Geological Survey's one-inch maps as well as a memoir on gypsum and anhydrite. The latter subject he amplified later when dealing with facies problems in the PermoTriassic related to evaporite deposition and stratal correlation.

Hollingworth was selected for the Geology Chair at University College, London, in 1946, in succession to W. B. R. King, who moved to Cambridge. He proved to be an invigorating teacher. His special attributes were to develop competence in field geology and an appreciation of the industrial applications of the subject. He initiated research by his students in south-west Ireland and, subsequently, he established research groups in the Caledonian orogenic belt of northern Norway and later in Chile.

Hollingworth had exceptional gifts in debating the results of almost any geological research and thus was a stimulating but always friendly critic. These gifts were canalized into the affairs of the Geological Society of London, which he sorved as Secretary from 1949 to 1956 and as Vice-President (1956-58 and 1962-64). He was President from 1960 to 1962 and received the Society's Murchison Medal in 1959. He leaves a widow and two sons.

C. J. Stubblefield

\section{Prof. P. Maheshwari}

The sudden and untimely death of Professor Panchanan Maheshwari on May 18, 1966, at Delhi, where he was head of the Department of Botany at the University, is a sad loss to botany not only in India but throughout the world. His was a dynamic and stimulating personality and nobody who met him could fail to be impressed by his enorgy, sincerity and simplicity, even if these good qualities were occasionally masked by an arroganee that could be misunderstood by those who failed to see beneath it. Maheshwari was a man of boundless energy and high ideals who set himself and his colleagues a very high standard in all the scientific work which they undertook. He could tolerate nothing that was second rate and he did not mince his words when he encountered inefficiency or obstruction in any shape or form. He was a good teacher with a broad outlook who not only inspired but also really cared for his students, who held him in high regard. And yet this broadness of vision was accompanied by ability to conduct research of a very high order in a specialized field, and his life's work on the embryology of plants is known throughout the botanical world.

Maheshwari was born at Jaipur on November 9, 1904 , where he later went to school before proceeding to the Ewing Christian College, Allahabad, in 1921, graduating in 1925. Here, ably influenced and guided by the late Dr. Winfield Dudgeon, an American missionary teacher, he took his M.Sc. and D.Sc. degrees at the University of Allahabad in 1927 and 1931, respectively. Joining the staff of Agra College, Agra, in 1930, he became associate professor in 1936. Subsequent appointments were at the University of Allahabad (1937-39), Lucknow (briefly in 1939), and he became reader and head of the department of biology at the University of Dacca later the same year. The best-known period of his career began in 1949 when he was appointed professor and head of the Department of Botany at the University of Delhi, a post which he continued to hold until he died.

Maheshwari travelled widely. During his first visit to Europe in 1936-37 he was greatly inspired by meeting the eminent embryologist Professor Karl Schnarf of Vienna, who gave him the idea of writing $A n$ Introduction to the Embryology of Angiosperms, which was completed at Harvard University in 1945. He was a member of and held office in numerous scientific societies, but, of these, perhaps particular attention should be directed to the fact that he was president of the Indian Botanical Society in 1951 and became founder and first president of the International Society of Plant Morphologists in the same year. This last society is responsible for publishing the journal Phytomorphology, first issued in 1951 and of which Mahoshwari has been the sole editor.

Maheshwari's An Introduction to the Embryology of Angiosperms has for many years been widely recognized as the leading textbook on the subject written in English, and a Russian translation has also been published. The more recent Advances in the Embryology of Angiosperms, edited by Maheshwari and published in 1963, is also widely used. It is impossible here to survey his numerous publications in scientific journals and it must suffice to say that until quite recently most of them fell into the broad field of descriptive morphology with special emphasis on the embryology of flowering plants, using the term embryology in the broadest possible sense. With his marked capacity for sifting and arranging factual information, Maheshwari, having mastered a wealth of detail, classified and clarified the main lines of variation in plant embryology that are known to occur. He also discussed the taxonomic and phylogenetic conclusions that can bo drawn from embryological knowledge. In recent years he turned his attention to the experimental side of embryology, and some investigations on this important aspect were still in progress when he died.

Because of Maheshwari's influence, the study of plant embryology and floral morphology has assumed an important role in the development of botany in India in recent decades, especially among $\mathrm{Ph}$.D. students. There may be some who fecl that these research exercisos have been too repetitive. It must be remembered, however, that theoretical conclusions based on descriptive aspects of botany are likely to be invalid unless they are supported by factual information drawn from investigations that are extensive and thorough. It was because Maheshwari realized that this is so, and because of his heavy teaching and administrative duties, that he adopted the only course open to him in seeking the aid of many collaborators and students to achieve his aim. The result must bo judged from the synthesis of these exercises which Maheshwari achieved rather than on the individual researches themselves, however valuable these may be. Viewed in this light, Maheshwari's contribution to botany is a notable one, especially when we remember that he himself regarded his own work as only a part of the even broader synthesis of descriptive botany that will become possible when his contribution has been added to that of related morphological disciplines.

Maheshwari, who was married at the age of 13, is survived by his widow and by three sons and three daughters.

I thank Professor B. M. Johri and other colleagues of the late Professor Maheshwari for providing some of the particulars included in this notice. C. R. METCATFE 